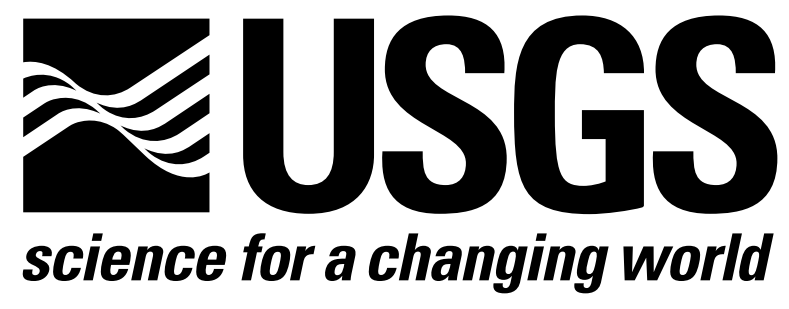

\title{
Biostratigraphy of the San Joaquin Formation in Borrow-Source Area B-17, Kettleman Hills Landfill, North Dome, Kettleman Hills, Kings County, California
}

By Charles L. Powell, II, Lanny H. Fisk, David F. Maloney, and David M. HaasI

Open-File Report 2010-1140

U.S. Department of the Interior

U.S. Geological Survey 


\title{
U.S. Department of the Interior \\ KEN SALAZAR, Secretary
}

\author{
U.S. Geological Survey \\ Marcia K. McNutt, Director
}

\section{U.S. Geological Survey, Reston: Virginia 2010}

For product and ordering information:

World Wide Web: http://www.usgs.gov/pubprod

Telephone: 1-888-ASK-USGS

For more information on the USGS - the Federal source for science about the Earth, its natural and living resources, natural hazards, and the environment:

World Wide Web: http://www.usgs.gov

Telephone: 1-888-ASK-USGS

Suggested citation:

Powell, C.L., II, Fisk, L.H., Maloney, D.F., and Haasl, D.M., 2010, Biostratigraphy of the San Joaquin Formation in borrow-source area B-17, Kettleman Hills landfill, North Dome, Kettleman Hills, Kings County, California: U.S. Geological Survey Open-File Report 2010-1140, 29 p. and oversized figure [http://pubs.usgs.gov/of/2010/1140/].

Any use of trade, product, or firm names is for descriptive purposes only and does not imply endorsement by the U.S. Government.

Although this report is in the public domain, permission must be secured from the individual copyright owners to reproduce any copyrighted material contained within this report. 


\section{Contents}

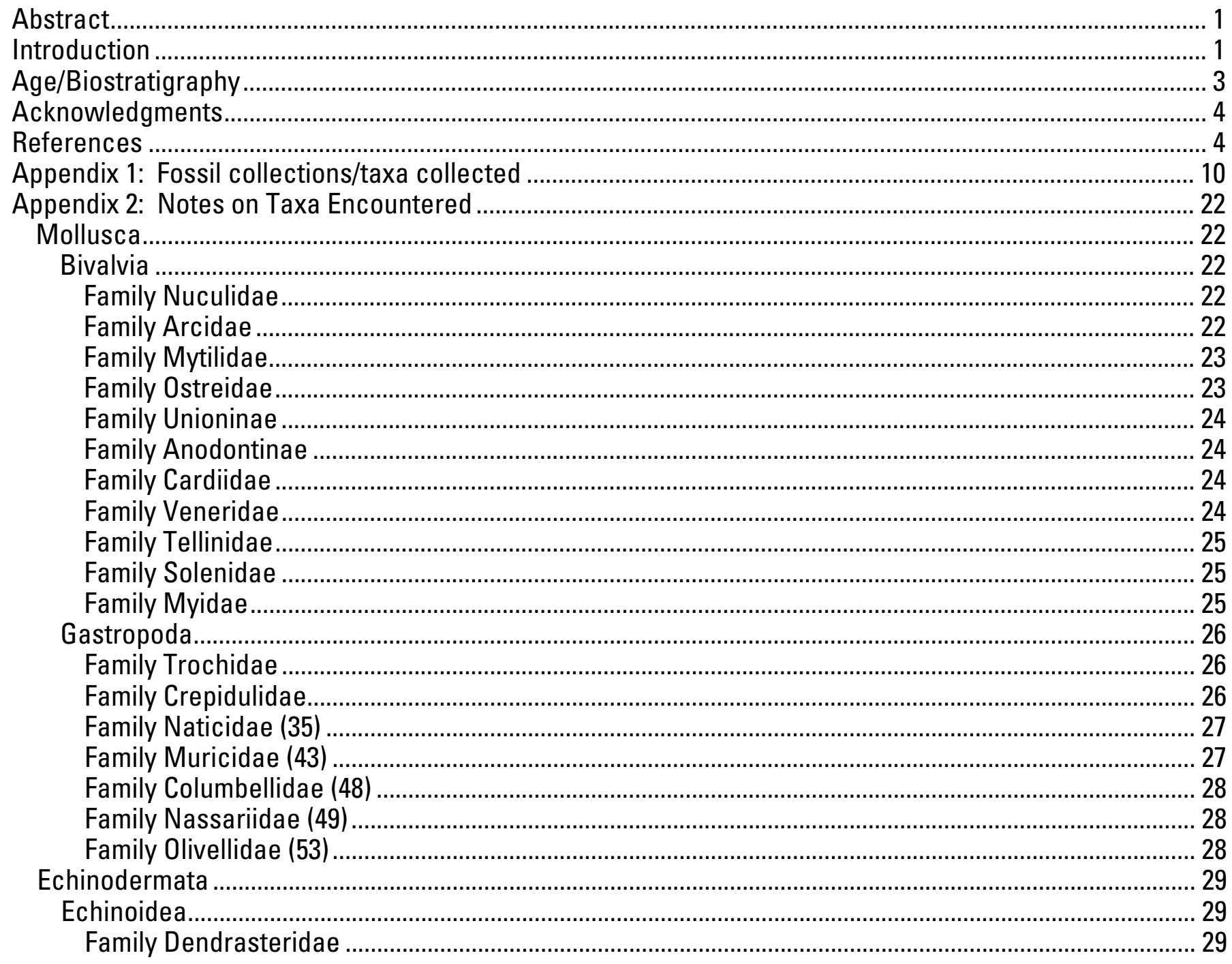

\section{Figures}

1. Index map showing location of Chemical Waste Management Kettleman Hills Landfill borrow-source area B-17

2. Stratigraphic section, sample localities, and stratigraphic occurrence of invertebrate taxa from CWM Kettleman Hills Landfill borrow-source area B-17 loversized figure at 


\title{
Biostratigraphy of the San Joaquin Formation in Borrow-Source Area B-17, Kettleman Hills Landfill, North Dome, Kettleman Hills, Kings County, California
}

\author{
By Charles L. Powell, II', Lanny H. Fisk'2, David F. Maloney², and David M. Haasl ${ }^{2}$
}

\begin{abstract}
The stratigraphic occurrences and interpreted biostratigraphy of invertebrate fossil taxa in the upper San Joaquin Formation and lower-most Tulare Formation encountered at the Chemical Waste Management Kettleman Hills waste disposal facility on the North Dome of the Kettleman Hills, Kings County, California are documented. Significant new findings include (1) a detailed biostratigraphy of the upper San Joaquin Formation; (2) the first fossil occurrence of Modiolus neglectus; (3) distinguishing Ostrea sequens from Myrakeena veatchii (Ostrea vespertina of authors) in the Central Valley of California; (4) differentiating two taxa previously attributed to Pteropurpura festivus; (5) finding a stratigraphic succession between Caesia coalingensis (lower in the section) and Catilon iniquus (higher in the section); and (6) recognizing Pliocene-age fossils from around Santa Barbara. In addition, the presence of the bivalves Anodonta and Gonidea in the San Joaquin Formation, both restricted to fresh water and common in the Tulare Formation, confirm periods of fresh water or very close fresh-water environments during deposition of the San Joaquin Formation.
\end{abstract}

\section{Introduction}

Development of a new site for waste deposition at the Kettleman Hills Landfill, Kings County, California (fig. 1) allowed employees from PaleoResource Consultants (Auburn, Calif.) to collect stratigraphically accurately placed fossil samples from a well-exposed section through the middle and upper part of the San Joaquin Formation and lower part of the Tulare Formation in the North Dome of the Kettleman Hills, Kings County, central California. This report documents mega-invertebrate fossil distribution (appendix 1), plots the invertebrate biostratigraphy in the section, and discusses the stratigraphic occurrences and ecologic significance of the species encountered (appendix 2), including a few new to the San Joaquin Formation. New and interesting information recognized during this study, includes (1) the first fossil occurrence of Modiolus neglectus; (2) distinguishing Ostrea sequens from Myrakeena veatchii (Ostrea vespertina of authors) in the Central Valley of California; (3) differentiating two taxa previously attributed to Pteropurpura festivus; (4) finding a stratigraphic succession between Caesia coalingensis (lower in the section) and Catilon iniquus (higher in the section); and (5) recognizing Pliocene age fossils from around Santa Barbara.

The Chemical Waste Management Kettleman Hills borrow-source area landfill area B-17 section is slightly less than $400 \mathrm{~m}$ thick and is composed of alternating sands and silt beds. The section, along with the record of fossil invertebrate occurrences, is illustrated in figure 2. The borrow-pit section is no longer exposed, having been lined to prevent leakage of waste into the local groundwater, and is in the process of being filled with waste.

\footnotetext{
${ }^{1}$ U.S. Geological Survey, Menlo Park, Calif.; cpowell@ usgs.gov

${ }^{2}$ PaleoResource Consultants, Auburn, Calif.
} 

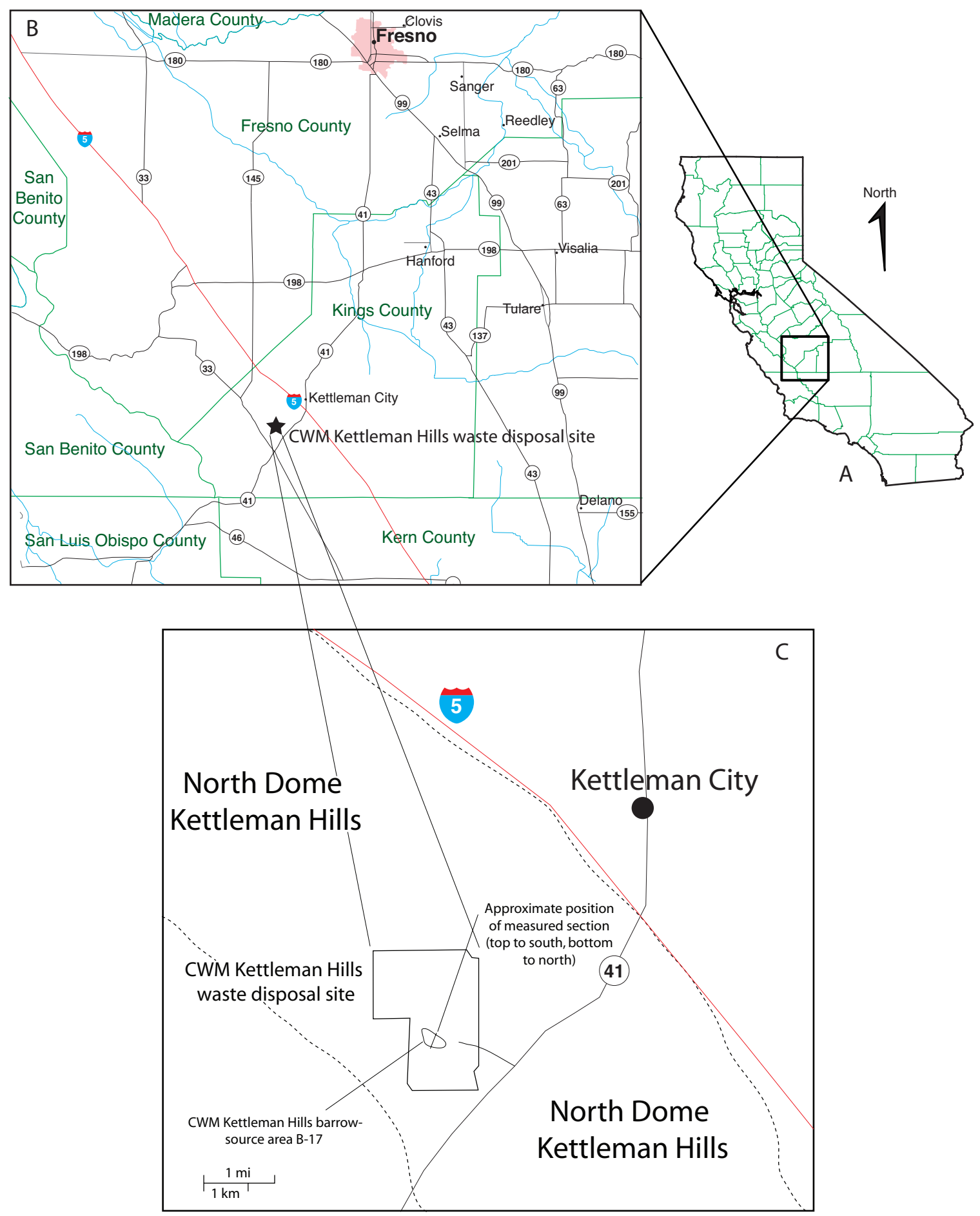

Figure 1. Location of the Chemical Waste Management (CWM) Kettleman Hills waste disposal site. $A$, Index map of California; $B$, Map of parts of Fresno, Kern, Kings, Madera, San Benito, and San Luis Obispo counties showing location of the CWM Kettleman Hills waste disposal site, interstate highways (red), California State highways (black), county boundaries (green), and rivers (blue); $C$, Details of CWM Kettleman Hills waste disposal site, with location of borrow-source area B-17 and approximate position of the measured section. 
Fifty-seven samples were examined during this study. The faunal zones of Arnold (1909) and Arnold and Anderson (1909 [1910]), as modified by Woodring and others (1940 [1941]) were recognized, allowing for inclusion of these samples into a composite section for the North Dome of the Kettleman Hills and a better understanding of the biostratigraphy of the Pliocene of central California.

\section{Age/Biostratigraphy}

Based on fossil mollusks the San Joaquin Formation is Pliocene in age (Woodring and others, 1940 [1941]). Potassium/Argon dating of the San Joaquin Formation and underlying Etchegoin Formation in the Kettleman Hills yields a numerical age range for the San Joaquin between about 4.5 and 2.5 Ma (see summary in Hosford Scheirer and Magoon, 2007), or early to middle, possibly late Pliocene (using U.S. Geological Survey Fact sheet 2007-3015, and the International Stratigraphic Chart for 2004, http://norges.uio.no/timescale/F2_chart.pdf, accessed 2/2010). Updated International Stratigraphic Charts (http://www.stratigraphy.org/upload/ISChart2009.pdf, accessed 2/2010) have not been adopted by the U.S. Geological Survey, but would give an early to late Pliocene, possibly earliest Pleistocene age for the San Joaquin Formation.

The biostratigraphy used here follows that proposed by Arnold (1909 [1910]) as modified by Woodring and others (1940 [1941]). As pointed out by Stanton and Dodd (1976), the stratigraphic ranges of many prominent invertebrate taxa in central California (and elsewhere) may reflect only a small portion of each taxon's total range. The local range results from a complex interplay of (1) the total potential range; (2) the portion of the enclosing section where environmental parameters would allow the taxon to be present; (3) chance, that is to say the taxon was present among the suite of creatures in the specific location represented by the fossil locality; and (4) taphonomy, preburial, and diagenetic conditions which allow a taxon to be preserved. Documenting the stratigraphic occurrences of various taxa in a well-exposed stratigraphic section allows for the development of detailed biostratigraphy that aids in correlating and dating similar-age rocks throughout California and elsewhere in western North America.

The stratigraphic section once exposed in the Kettleman Hills Landfill borrow-source area B-17 included both the San Joaquin and Tulare formations. The occurrence of marine fossils below the top of the San Joaquin Formation indicate a shallow marine environment of mostly mud, silt, and sand with occasional conglomerates. The occurrence of fresh-water mollusks indicates the base of the Tulare Formation and the end of marine deposition in the area, although scattered occurrences of fresh-water mollusks in the San Joaquin Formation indicate that fresh-water conditions may have occurred occasionally during deposition of the San Joaquin Formation (perhaps during sea-level low stands), or that the fresh-water environment was not far away. Furthermore, the occurrence of Anadara trilineata into the Tulare Formation indicates a marine environment in close proximity to the fresh-water environment represented by that formation.

The stratigraphic range of extant and extinct species in the section could be due to environmental parameters favorable for their occurrence and subsequent deposition and preservation. However, the stratigraphic range of extinct species also could represent their stratigraphic ranges. Further data in welldated sections is needed to determine accurately the stratigraphic ranges of extinct species. Figure 2 plots the stratigraphic ranges of extinct species in the CWM Kettleman Hills Landfill section. With the exception of Pteropurpura aff. P. festivus, which has yet to be adequately distinguished from the nominal species, the last occurrence of Caesia coalingensis, and the first occurrence Catilon iniquus, all these stratigraphic ranges are assumed to be due to environmental factors as they are all known to occur elsewhere in California over a broader stratigraphic interval. The stratigraphic succession of the nassariids Caesia coalingensis and Catilon iniquus appears to represent an evolutionary succession as there is no apparent significant change in environment during the interval where the change occurs. If this succession is found elsewhere in the San Joaquin Formation and (or) in other formations at about 
the same time, and that time can be dated, then a detailed, well-dated biostratigraphy for this part of the California Neogene can be developed.

\section{Acknowledgments}

The authors thank Russ Graymer (USGS), Lindsey Groves (Los Angeles County Natural History Museum, Calif.) and Mary McGann (USGS) for offering helpful suggestions for improving the manuscript. Chemical Waste Management is thanked for allowing the collection of fossils from their Kettleman Hills Facility, for financial support, and for allowing publication of this report.

Patrick W. Riseley is thanked for measuring a detailed stratigraphic section of the San Joaquin Formation exposed in borrow-source area B-17 from which the generalized section in this report is derived. We also thank former PaleoResource Consultants employees Jason C. Butler, Eric S. Gore, Russ E. Hasting, Patrick W. Riseley, and Jaspal S. Saini for collecting specimens.

\section{References}

Abbott, R.T., 1974, American seashells-The marine Mollusca of the Atlantic and Pacific coasts of North America: New York, Van Nostrand Reinhold Co., 663 p.

Addicott, W.O., 1965, Some western American Cenozoic gastropods of the genus Nassarius: U.S. Geological Survey Professional Paper 503B, p. B1-B24.

Addicott, W.O., 1966, Late Pleistocene marine paleoecology and zoogeography in central California: U.S. Geological Survey Professional Paper 523C, p. C1-C21.

Addicott, W.O., 1970, Miocene gastropods and biostratigraphy of the Kern River area, California: U.S. Geological Survey Professional Paper 642, 174 p.

Addicott, W.O., and Vedder, J.G., 1963, Paleotemperature inferences from Miocene mollusks in the San Luis Obispo-Bakersfield area, California: U.S. Geological Survey Professional Paper 475C, p. C63-C68.

Addicott, W.O., Barron, J.A., and Miller, J.W., 1978, Marine late Neogene sequence near Santa Cruz, California, in Addicott, W.O., ed., Neogene biostratigraphy of selected areas in the California Coast Ranges: U.S. Geological Survey Open-File Report 78-446, p. 97-109.

Adegoke, O.S., 1969, Stratigraphy and paleontology of the marine Neogene formations of the Coalinga region, California: University of California Publications in Geological Sciences, v. 80, 241 p.

Allen, J.E., 1946, Geology of the San Juan Bautista Quadrangle, California: Berkeley, University of California, Ph.D. dissertation, 94 p.

Arnold, R.A., 1903, The paleontology and stratigraphy of the marine Pliocene and Pleistocene of San Pedro, California: California Academy of Sciences Memoir, v. 3, 420 p.

Arnold, R.A., 1906, The Tertiary and Quaternary pectens of California: U.S. Geological Survey Professional Paper 47, 264 p.

Arnold, R.A., 1907a, Geology and oil resources of the Summerland District, Santa Barbara County, California: U.S. Geological Survey Bulletin 321, 93 p.

Arnold, R.A., 1907b, New and characteristic species of fossil mollusks from the oil-bearing Tertiary formations of Santa Barbara County, California: Smithsonian Miscellaneous Collections, v. 50, p. 419-447.

Arnold, R.A., 1908, Description of new Cretaceous and Tertiary fossils from the Santa Cruz Mountains, California: U.S. National Museum Proceedings, v. 34, p. 345-390.

Arnold, R.A., 1909, Paleontology of the Coalinga District, Fresno and Kings Counties, California: U.S. Geological Survey Bulletin 396, 173 p.

Arnold, R.A., and Anderson, R., 1907, Geology and oil resources of the Santa Maria oil district, Santa Barbara County, California: U.S. Geological Survey Bulletin 322, 161 p. 
Arnold, R.A., and Anderson, R., 1909 [1910], Geology and oil resources of the Coalinga District, California: U.S. Geological Survey Bulletin 398, 354 p.

Arnold, R.A., and Hannibal, H., 1913, The marine Tertiary stratigraphy of the north Pacific Coast: American Philosophical Society Proceedings, v. 3, p. 576-585.

Bernard, F.R., 1983, Catalogue of the living Bivalvia of the eastern Pacific Ocean-Bering Strait to Cape Horn: Canadian Special Publication of Fisheries and Aquatic Sciences, no. 61, 102 p.

Burch, J.Q., ed., 1944-1946, Distributional list of the west American marine Mollusca from San Diego, California to the Polar Sea: Minutes of the Conchological Club of southern California, pt. 1 (Pelecypods), nos. 33-45 (March 1944-February 1945); pt. 2, v. 1-2 (Gastropoda), nos. 46-63 (March 1945-September 1946).

Carson, C.M., 1925, Some new species from the Pliocene of southern California, with a few changes in nomenclature: Southern California Academy of Sciences Bulletin, v. 24, p. 31-35.

Clark, A., 1931, The cool-water Timms Point Pleistocene horizon at San Pedro, California: San Diego Society of Natural History Transactions, v. 7, p. 25-42.

Clark, B.L., 1915, Fauna of the San Pablo group of middle California: University of California Publications, Bulletin of the Department of Geology, v. 8, p. 385-572, pls. 42-71.

Clark, B.L., 1929, Stratigraphy and faunal horizons of the Coast Ranges of California: Privately printed, $132 \mathrm{p}$.

Coan, E.V., 1971, The Northwest American Tellinidae: The Veliger, supplement to v. 14, p. 1-63.

Coan, E.V., Scott, P.V., and Bernard, F.R., 2000, Bivalve seashells of western North America: Marine bivalves mollusks from Arctic Alaska to Baja California: Santa Barbara Museum of Natural History Monographs no. 2, Studies in Biodiversity no. 2, 764 p.

Conrad, T.A., 1857, Description of the Tertiary fossils collected on the survey [Williamson's survey], in Reports of explorations and surveys *** railroad *** from the Mississippi River to the Pacific Ocean: U.S. 33d Congress, 2d session, Senate Ex. Doc. 78 and House Ex. Doc. 91, v. 6, pt. 2, p. 69-73.

Cummings, J.C., Touring, R.M., and Brabb, E.E., 1962, Geology of the northern Santa Cruz Mountains, California, in Bowen, O.E., Jr., ed., Geologic guide to the gas and oil fields of northern California: California Division of Mines Bulletin, no. 181, p. 179-220.

Dall, W.H., 1917, Summary of the mollusks of the family Alectrionidae of the west coast of America. U.S. National Museum Proceedings, v. 51, p. 575-579.

DeLong, J.H., Jr., 1941, The paleontology and stratigraphy of the Pleistocene at Signal Hill, Long Beach, California: San Diego Society of Natural History Transaction, v. 9, p. 229-252.

Dibblee, T.W., Jr., 1966, Geology of the central Santa Ynez Mountains, Santa Barbara County, California: California Division of Mines and Geology Bulletin, no. 186, 99 p.

Durham, D.L., 1974, Geology of the southern Salinas Valley area, California: U.S. Geological Survey Professional Paper 819, 111 p.

Durham, D.L., and Addicott, W.O., 1965, Pancho Rico Formation, Salinas Valley, California: U.S. Geological Survey Professional Paper 525-A, p. A1-A22.

Durham, D.L., and Yerkes, R.F., 1964, Geology and oil resources of the eastern Puente Hills area, southern California: U.S. Geological Survey Professional Paper 420B, p. B1-B62.

Eaton, J.E., 1928, Division and duration of the Pleistocene in southern California: American Association of Petroleum Geologists Bulletin, v. 12, p. 111-141.

Eldridge, G.H., and Arnold, R., 1907, The Santa Clara Valley, Puente Hills, and Los Angeles oil districts, southern California: U.S. Geological Survey Bulletin 309, 266 p.

Emerson, W.K., 1980, Invertebrate faunules of late Pleistocene age, with zoogeographic implications, from Turtle Bay, Baja California Sur, Mexico: The Nautilus, v. 94, p. 67-89.

English, W.A., 1914, The Fernando Group near Newhall, California: University of California Publications, Bulletin of the Department of Geology, v. 8, p. 203-218. 
Erlandson, J.M., Rick, T.C., Collins, P.W., and Guthrie, D.A., 2007, Archaeological implications of a bald eagle nesting site at Ferrelo Point, San Miguel Island, California: Journal of Archaeological Science, v. 34, p. 255-271.

Fahy, N.E., 1974, Origin of Lake Merced. California: Geology, v. 27, p. 171-174.

Faustman, W.F., 1964, Paleontology of the Wildcat Group at Scotia and Centerville Beach, California: University of California Bulletin Publications in Geological Sciences, v. 41, p. 97-160.

Foster, N. R., 1991, Intertidal bivalves-A guide to the common marine bivalves of Alaska: Fairbanks, AK. University of Alaska Press, 152 p.

Gifford D.S., and Gifford, E.W., 1948, Oregonian olivellas: Nautilus, v. 62, p. 51-54.

Glen, W., 1959, Pliocene and lower Pleistocene of the western part of the San Francisco Peninsula: University of California Publications in Geological Sciences, v. 36, p. 147-198.

Grant, U.S., IV and Gale, H.R., 1931, Catalogue of the marine Pliocene and Pleistocene Mollusca of California and adjacent regions; with notes on their morphology, classification, and nomenclature and a special treatment of the Pectinidae and the Turridae (including a few Miocene and recent species; together with a summary of the stratigraphic relations of the formations involved: San Diego Society of Natural History Memoir no. 1, 1,036 p.

Grant, U.S., IV, and Hertlein, L.G., 1938, The west American Cenozoic Echinoidea: Publications of the University of California at Los Angeles in Mathematical and Physical Sciences, v. 2, 226 p.

Groves, L.T., 1991, Molluscan paleontology of the Pliocene-Pleistocene lower Saugus Formation, southern California: American Conchologist, v. 19, p.16-17.

Hall, C.A., 1960, Displaced Miocene molluscan provinces along the San Andreas fault, California: University of California Publications in Geological Sciences, v. 34, p. 281-308.

Hertlein, L.G., and Grant, U.S., IV, 1972, The geology and paleontology of the marine Pliocene of San Diego, California (Paleontology: Pelecypoda): San Diego Society of Natural History Memoir 2, pt. 2B: 143-409 p.

Hetherington, G.E., 1957, Geology of the south Tapo Canyon area, Santa Susana quadrangle, Ventura County, California: Los Angeles, University of California, master thesis, 93 p.

Hoots, H.W., 1930, Geology of the eastern part of the Santa Monica Mountains, Los Angeles County, California: U.S. Geological Survey Professional Paper 165C, p. 83-134.

Hosford Scheirer, A., and Magoon, L.B., 2007, Age, distribution, and stratigraphic relationship of rock units in the San Joaquin Basin Province, California, Chapter 5 in Petroleum systems and geologic assessment of oil and gas in the San Joaquin Basin Province, California: U.S. Geological Survey Professional Paper 1713, 107 p., http://pubs.usgs.gov/pp/pp1713/05/.

Howe, H.V., 1922, Faunal and stratigraphic relationships of the Empire Formation, Coos Bay, Oregon: University of California Publications, Department of Geological Sciences Bulletin, v. 14, p. 85114.

Johnson, R.G., 1962, Mode of formation of marine fossil assemblages of the Pleistocene Millerton Formation of California: Geological Society of America Bulletin, v. 73, p. 113-130.

Jordan, E.K., 1926, Molluscan fauna of the Pleistocene of San Quintin Bay, Lower California: California Academy of Sciences Proceedings, series 4, v. 15, p. 241-254.

Kanakoff, G.P., and Emerson,W.K., 1959, Late Pleistocene invertebrates of the Newport Bay area, California: Los Angeles County Museum Contributions in Science, no. 31, 47 p.

Kennedy, G.L., 1975, Paleontologic record of areas adjacent to the Los Angeles and Long Beach Harbors, Los Angeles County, California: Allan Hancock Expedition, Marine Studies of San Pedro Bay, California, pt. 9, paleontology, p. 1-119.

Kennedy, G.L., 1978, Pleistocene paleoecology, zoogeography, and geochronology of marine invertebrate faunas of the Pacific northwest coast (San Francisco Bay to Puget Sound): Davis, University of California, Ph.D. disseratation, 824 p. 
Keen, A.M., 1943, New mollusks from the Round Mountain Silt (Temblor) Miocene of California: San Diego Society of Natural History Transaction, v. 10, p. 25-60.

Kern, J.P., 1973, Early Pliocene marine climate and environment of the eastern Ventura basin southern California: University of California Publications in Geological Sciences, v. 96, 117 p.

Kern, J.P., and Wicander, E. R., 1974, Origin of a bathymetrically displaced marine invertebrate fauna in the upper part of the Capistrano Formation (lower Pliocene), southern California: Journal of Paleontology, v. 48, p. 495-505.

Kew, W.S.W., 1920, Cretaceous and Cenozoic Echinoidea of the Pacific Coast of North America: University of California Publications, Bulletin of the Department of Geology, v. 12, p. 23-236.

Kew, W.S.W., 1924, Geology and oil resources of a part of Los Angeles and Ventura Counties, California: U.S. Geological Survey Bulletin 753, 202 p.

Kohl, R.F., 1974, A new late Pleistocene fauna from Humboldt County, California: The Veliger, v. 17, p. 211-219.

Lajoie, K.R., Ponti, D J., Powell, C.L., II, Mathieson, S.A., and Sarna-Wojcicki, A.M. , 1991, Emergent marine strandlines and associated sediments, coastal California-A record of Quaternary sealevel fluctuations, vertical tectonic movements, climatic changes, and coastal processes, in Morrison, R.B., ed., Quaternary nonglacial geology: Conterminous U.S. The geology of North America, vol. K-2, Geological Society of America (Boulder, Colorado), p. 190-214.

Loel, W., and Corey, W.H., 1932, The Vaqueros Formation, lower Miocene of California. I. Paleontology: University of California Publications Bulletin of the Department of Geological Sciences, v. 22, p. 31-410.

MacNeil, F.S., 1965, Evolution and distribution of the genus Mya, and Tertiary migrations of Mollusca: U.S. Geological Survey Professional Paper 483G, p. G1-G51.

Marincovich, L.N., Jr., 1976, Late Pleistocene molluscan faunas from the upper terraces of the Palos Verdes Hills, California: Natural History Museum of Los Angeles County, Contributions in Science no. 281, 28 p.

Marincovich, L.N., Jr., 1977, Cenozoic Naticidae (Mollusca: Gastropoda) of the northeastern Pacific: American Paleontology Bulletin, v. 70, p. 165-494.

Martin, B., 1916, The Pliocene of middle and northern California: University of California Publications, Bulletin of the Department of Geology, v. 9, p. 215-259.

McLean, J.H., 1978, Marine shells of southern California: Natural History Museum of Los Angeles County, Science Series, no. 24, 94 p.

McLean, J.H., 1996, The Prosobranchia, in McLean, J.H. and Gosliner, T.M., The Gastropoda: Taxonomic atlas of the benthic fauna of the Santa Maria Basin and western Santa Barbara Channel, v. 9, The Mollusca, pt. 2, 228 p.

McLean, J.H., 2007, Gastropoda, Shelled Gastropods, in Carlton, J.T., ed., The Light and Smith Manual. Intertidal invertebrates from central California to Oregon (4th ed.): Berkeley, University of California Press, p. 713-766.

McLean, J.H., and Grosliner, T.M., 1996, The Gastropoda, in Taxonomic atlas of the benthic fauna of the Santa Maria Basin and western Santa Barbara Channel, v. 9, The Mollusca, pt. 2, The Gastropoda, 228 p.

Meade, R.F., 1967, Molluscan paleoecology of the Fernando Group of southern Ventura Basin: Los Angeles, University of California, Ph.D. disseration, 154 p.

Minor, S.A., Kellogg, K.S., Stanley, R.G., Stone, P., Powell, C.L., II, Gurrola, L.D., Selting, A.J., and Bradt, T.R., 2002, Preliminary geologic map of the Santa Barbara coastal plain area, Santa Barbara County, California: U.S. Geological Survey Open-File Report 02-136, scale 1:24,000, 36 p., http://pubs.usgs.gov/of/2002/ofr-02-0136/

Moody, C.L., 1916, Fauna of the Fernando of Los Angeles: University of California Publications, Bulletin of the Department of Geology, v. 10, p. 39-62. 
Moore, E.J., 1983, Tertiary marine pelecypods of California and Baja California-Nuculidae through Malleidae: U.S. Geological Survey Professional Paper 1228A, p. A1-A108.

Moore, E.J., 1987, Tertiary marine pelecypods of California and Baja California-Plicatulidae to Ostreidae: U.S. Geological Survey Professional Paper 1228C, p. C1-C53.

Moore, E.J., 2002, Family Cardiidae, in Tertiary marine pelecypods of California and Baja California, Chapter F: http://members.peak.org/ chintimp/Cardiidae.htm, $21 \mathrm{p}$.

Nomland, J.O., 1916, Fauna from the lower Pliocene at Jacalitos Creek and Waltham Canyon, Fresno County, California: University of California Publications, Bulletin of the Department of Geology, v. 9, p. 199-214.

Nomland, J.O., 1917a, The Etchegoin of middle California: University of California Publications, Bulletin of the Department of Geology, v. 10, p. 191-254.

Nomland, J.O., 1917b, Fauna of the Santa Margarita beds in the north Coalinga region of California: University of California Publications, Bulletin of the Department of Geology, v. 10, p. 293-326.

Oakeshott, G.B., 1958, Geology of the Placerita oil field, Los Angeles County, California: California Journal of Mines and Geology, v. 46, p. 43-82.

Ogle, B.A., 1953, Geology of the Eel River Valley area, Humboldt County, California: California Division of Mines Bulletin 164, 128 p.

Oldroyd, I.S., 1924, Marine shells of Puget Sound and vicinity: Publications of the Puget Sound Biological Station of the University of Washington, v. 4, 272 p.

Oldroyd, I.S., 1925, The fossils of the lower San Pedro fauna of the Nob Hill cut, San Pedro, California: U.S. National Museum Proceedings, v. 65, art. 22, p. 1-39.

Oldroyd, I.S., and Grant, U.S., IV, 1931, A Pleistocene molluscan fauna from near Goleta, Santa Barbara County, California: The Nautilus, v. 44, p. 91-94.

Peck, J.H., 1960, Paleontology and correlation of the Ohlson Ranch Formation: University of California Publications in Geological Sciences, v. 36, p. 233-242.

Perry, F.A., 1993, Fossil invertebrates and geology of the marine cliffs at Capitola, California: Santa Cruz, Calif. Santa Cruz City Museum, p. 1-30.

Powell, C.L., II, 1998, The Purisima Formation and related rocks (upper Miocene-Pliocene), greater San Francisco Bay area, central California; review of literature and USGS collections (now housed at the Museum of Paleontology, University of California, Berkeley): U.S. Geological Survey Open-File Report 98-594, 101 p.

Powell, C.L., II, 2001, Geologic and molluscan evidence for a previously misunderstood late Pleistocene cool water, open coast terrace at Newport Bay, southern California: The Veliger, v. 44, p. 340-347.

Powell, C.L., II, 2007, Outcrops and mollusks of the "Margaritan" California provincial molluscan stage in the northern Salinas Valley, Monterey and San Benito Counties, central California: PaleoBios, v. 27, p. 86-125.

Powell, C.L., II, Allen, J.R., and Holland, P.J., 2004, Invertebrate paleontology of the Wilson Grove Formation (late Miocene to late Pliocene), Sonoma and Marin Counties, California, with some observations on its stratigraphy, thickness, and structure: U.S. Geological Survey Open-File Report 2004-1017, 106 p.

Powell, C.L., II, Barron, J.A., Sarna-Wojcicki, A.M., Clark, J.C., Perry, F.A., Brabb, E.E., and Fleck, R.J., 2007, Age, stratigraphy, and correlation of the late Neogene Purisima Formation, central California Coast Ranges: U.S. Geological Survey Professional Paper 1740, 32 p.

Powell, C.L., II, Stanton, R.J., Jr., Vendrasco, M., and Liff-Grief, P., 2009, Warm extralimital fossil mollusks used to recognize the mid-Pliocene warm event in southern California: Western Society of Malacologists Annual Report for 2008, v. 41, p. 70-91. 
Powell, C.L., II, and Stevens, D., 2000, Age and paleoenvironmenal significance of mega-invertebrates from the "San Pedro" Formation in the Coyote Hills, Fullerton and Buena Park, Orange County, southern California: U.S. Geological Survey Open-File Report 00-319, 83 p.

Pressler, E.D., 1929, The Fernando Group in the Las Posas-South Mountain District, Ventura County, California: University of California Publications, Bulletin of the Department of Geological Sciences, v. 18, p. 325-345.

Rice, T., 1971, Marine shells of the Pacific northwest: Edomonds, Wash., Ellison Industries, Inc., 102 p. Rodda, P.U., 1957, Paleontology and stratigraphy of some marine Pleistocene deposits in northwest Los Angeles Basin, California: American Association of Petroleum Geologists Bulletin, v. 41, p. 2457-2492.

Roth, B., 1979, Late Cenozoic marine invertebrates from northwest California and southwest Oregon: Berkeley, University of California, Ph.D. dissertation, 792 p.

Rowland, R.W., 1972, Paleontology and paleoecology of the San Diego Formation in northwestern Baja California: San Diego Society of Natural History Transaction, v. 17, p. 25-32.

Schoellhamer, J.E., Vedder, J.G., Yerkes, R.F., and Kinney, D.M., 1981, Geology of the northern Santa Ana Mountains: U.S. Geological Survey Professional Paper 420D, p. D1-D109.

Soot-Ryen, T., 1955, A report on the family Mytilidae (Pelecypoda): University of southern California, Allan Hancock Fondation, Allan Hancock Pacific Expeditions, v. 20, 261 p.

Soper, E.K., and Grant, U.S., IV, 1932, Geology and paleontology of a portion of Los Angeles, California: Geological Society of America Bulletin, v. 43, p. 1041-1067.

Squires, R.L., Groves, L.T., and Smith, J.T., 2006, New information on molluscan paleontology and depositional environments of the upper Pliocene Pico Formation, Valencia area, Los Angeles County, southern California: Natural History Museum of Los Angeles County, Contributions in Science, no. 511, 27 p.

Stanton, R.J., Jr., 1966, Megafauna of the upper Miocene Castaic Formation, Los Angeles County, California: Journal of Paleontology, v. 40, p. 21-40.

Stanton, R.J., Jr., and Dodd, J.R., 1976, Pliocene biostratigraphy and depositional environment of the Jacalitos Canyon area, California, in Fritsche, A.E., TerBest, H., Jr., and Worardt, W.W., eds., The Neogene symposium: Society of Economic Paleontologists and Mineralogists, Annual meeting, p. 85-94.

Touring, R. M., 1959, Structure and stratigraphy of the La Honda and San Gregorio Quadrangles, San Mateo County, California: Stanford, Calif., Stanford University, Ph.D. dissertation, 228 p.

Valentine, J.W., 1956, Upper Pleistocene Mollusca from Potrero Canyon, Pacific Palisades, California: San Diego Society of Natural History Transaction, v. 12, p. 181-205.

Valentine, J.W., 1958, Late Pleistocene megafauna of Cayucos, California, and its zoogeographic significance: Journal of Paleontology, v. 32, p. 687-696.

Valentine, J.W., 1960, Habitats and sources of Pleistocene mollusks at Torrey Pines Park, California: Ecology, v. 41, p. 161-165.

Valentine, J.W., 1961, Paleoecologic molluscan geography of the Californian Pleistocene: University of California Publications in Geological Sciences v. 34, p. 309-442.

Valentine, J.W., and Lipps, J.H., 1963, Late Cenozoic rocky-shore assemblages from Anacapa Island, California: Journal of Paleontology, v. 37, p. 1292-1302.

Vedder, J.G., 1972, Review of stratigraphic names and megafaunal correlation of Pliocene rocks along the southeast margin of the Los Angeles Basin, in Stinemeyer, E.H., ed., Pacific Coast Miocene biostratigraphy symposium: Society of Economic Paleontologists and Mineralogists, Pacific Section, 47th, Bakerfield, Calif., Proceedings, 1972, p. 158-172.

Vedder, J.G., and Norris, R.M., 1963, Geology of San Nicolas Island, California: U.S. Geological Survey Professional Paper 369, 65 p. 
Waterfall, L.N., 1929, A contribution to the paleontology of the Fernando Group, Ventura Conty, California: University of California Publications, Bulletin Department Geological Science, v. 18, p. 71-92.

Weaver, C.E., 1909, Stratigraphy and paleontology of the San Pablo Formation in middle California: University of California Publications, Bulletin of the Department of Geology, v. 5, p. 243-269.

Weaver, C.E., 1949, Geology of the Coast Ranges immediately north of the San Francisco Bay region, California: Geological Society of America Memoir 35, 242 p.

Willett, G., 1937, Report on Pleistocene molluscan faunas of Capistrano Beach, Orange County, California: Southern California Academy of Sciences Bulletin, v. 36, p. 105-107.

Winterer, E.L., and Durham, D.L., 1962, Geology of southeastern Ventura Basin, Los Angeles County, California: U.S. Geological Survey Professional Paper 334H, p. H1-H366.

Woodring, W.P., 1938, Lower Pliocene mollusks and echinoids from the Los Angeles Basin, California: U.S. Geological Survey Professional Paper 190, 58 p.

Woodring, W.P., and Bramlette, M.N., 1950, Geology and paleontology of the Santa Maria District California: U.S. Geological Survey Professional Paper 222: 185 p.

Woodring, W.P., Bramlette, M.N., and Kew, W.S.W., 1946, Geology and paleontology of Palos Verdes Hills, California: U.S. Geological Survey Professional Paper 207, 145 p.

Woodring, W.P., Stewart, R., and Richards, R.W., 1940 [1941], Geology of the Kettleman Hills oil field, California: U.S. Geological Survey Professional Paper 195, 170 p.

Wright, R.H., 1972, Late Pleistocene marine fauna, Goleta, California: Journal of Paleontology, v. 46, p. 688-695.

Yancey, T.E., 1978, Stratigraphy of the Plio-Pleistocene strata in the Twelvemile Creek area, San Francisco Peninsula, California: California Academy of Sciences Proceedings, Fourth Series v. 41, p. 357-370.

Yerkes, R.F., 1972, Geology and oil resources of the western Puente Hills area, southern California:

U.S. Geological Survey Professional Paper 420C, p. C1-C63.

Zinsmeister, W.J., 1970, A late Pliocene macrofossil fauna of Newport Beach, Orange County, California: Southern California Academy of Sciences Bulletin, v. 69, p. 121-125.

\section{Appendix 1: Fossil collections/taxa collected}

Arranged alphabetically and numerically by field number as marked on the sample bags. Zone determinations below are from the field geologists and do not necessarily agree with determinations in figure 2 .

DFM collected by David F. Maloney. Field no.: DFM 11-12-01-02. Borrow-source area B-17, Acila zone, San Joaquin Formation. Mollusca

Bivalvia

Anadara trilineata (Conrad)

Field no.: DFM 12-12-01-01. Borrow-source area B-17, Trachycardium zone, San Joaquin Formation. Mollusca:

Bivalvia:

Anadara trilineata (Conrad)

Macoma? sp.

Mytilus cf. M. californianus Conrad

Saxidomus cf. S. latus Stewart

Solen? sp.

Tellina woodringi Adegoke

Trachycardium cf. T. quadrigenarium (Conrad) 


\section{Gastropoda}

Calliostoma cf. C. coalingensis Arnold

Calyptraea cf. C. inornata (Gabb)

Catilon cf. C. iniquus (Stewart)

Nassarius sp.

Naticidae, indeterminate

Neogastropoda, indeterminate

Field no.: DFM 12-12-01-03. Borrow-source area B-17, Neverita zone, San Joaquin Formation.

Mollusca

Bivalvia

Anadara trilineata (Conrad)

Ostrea cf. O. sequens Arnold

Gastropoda

Calyptraea cf. C. inornata (Gabb)

Naticidae, indeterminate

Field no.: DFM 18-02-08-02. Borrow-source area B-17, Tulare Formation.

Mollusca

Bivalvia

Anadara trilineata (Conrad)

Argopecten sp. [right valve \pm 20 ribs, low, rounded ribs with narrow interspaces]

Field no.: DFM 18-02-08-03. Borrow-source area B-17, San Joaquin Formation.

Mollusca

Gastropoda

Forreria sp.

Glossaulax reclusiana (Deshayes)

Echinodermata

Indeterminate gastropod (limpet)

Echinoidea

Dendraster cf. D. coalingensis Twitchell

Arthropoda

Maxillopoda

Balanus? sp.

Malacostraca

Indeterminate taxon

Field no.: DFM 18-02-08-04. Borrow-source area B-17, San Joaquin Formation.

Mollusca

Gastropoda

Caesia coalingensis (Arnold)

Naticidae, indeterminate

Pteropurpura aff. P. festiva (Hinds)

Echinodermata

Echinoidea

Dendraster cf. D. coalingensis Twitchell 
Field no.: DFM 18-12-01-01. Borrow-source area B-17, coquina layer, San Joaquin Formation. Mollusca

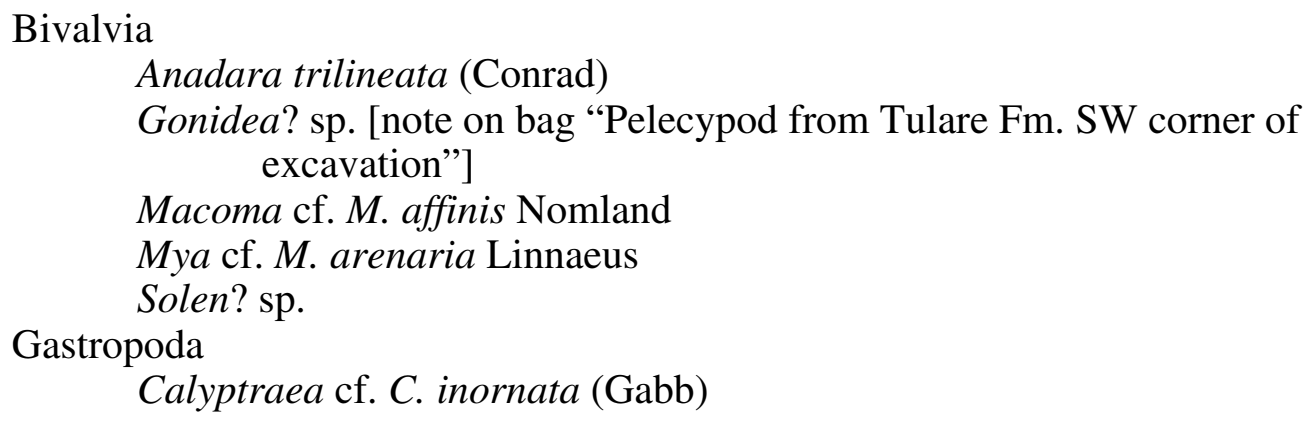

Field no.: DFM 23-01-02-01. Borrow-source area B-17, San Joaquin Formation.

Note with specimens: Gypsum layer, Acila zone.

Mollusca

Bivalvia

Acila castrensis (Hinds)

Anadara trilineata (Conrad)

Macoma cf. M. affinis Nomland

Modiolus sp.

Zirfaea sp.

Gastropoda

Calyptraea cf. C. inornata (Gabb)

Arthropoda

Catilon iniqua (Stewart)

Crepidula sp.

$$
\begin{aligned}
& \text { Maxillopoda } \\
& \text { Balanus sp. }
\end{aligned}
$$

Field no.: DFM 23-01-02-02. Borrow-source area B-17, gypsum zone, San Joaquin Formation.

Mollusca

$$
\begin{aligned}
& \text { Bivalvia } \\
& \text { Anadara trilineata (Conrad) } \\
& \text { Gastropoda } \\
& \quad \text { Calyptraea cf. C. inornata (Gabb) }
\end{aligned}
$$

Field no.: DFM 24-01-02-01. Borrow-source area B-17, San Joaquin Formation.

Note with specimens: Gastropods above gypsum zone, first layer in the Acila zone, Kettleman Hills, CA. B-17, 1:400'. Borrow-source area B-17, Acila zone, San Joaquin Formation.

Mollusca

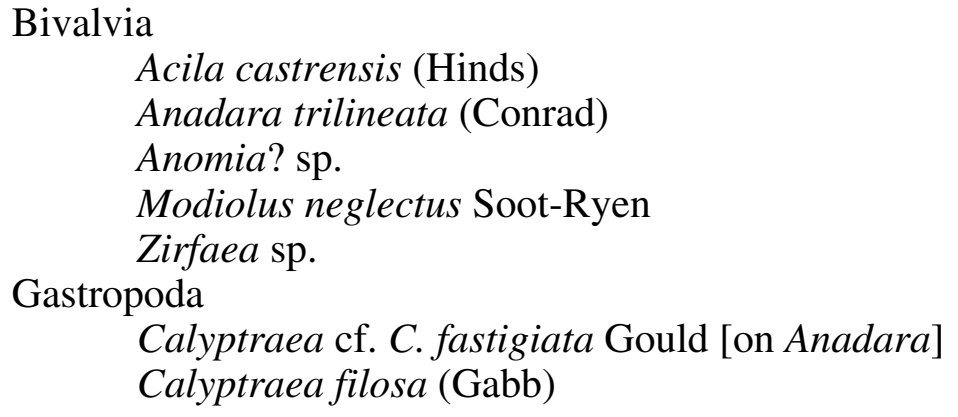




\author{
Crepidula? sp. \\ Diodora? sp. \\ Nassarius? sp. \\ Naticidae?, indeterminate \\ Trochid, indeterminate \\ Arthropoda \\ Malacostraca \\ Balanus? sp.
}

Field no.: DFM 24-01-02-02. Borrow-source area B-17, gypsum zone, San Joaquin Formation.

Mollusca

Gastropoda

Cerithiopsidae?, indeterminate

Field no.: DFM 24-01-02-03. Borrow-source area B-17, San Joaquin Formation.

Note with specimens: Lower oyster zone. Borrow-source area B-17, Acila zone, San Joaquin

Formation.

Mollusca

Bivalvia

Ostrea sequens Arnold

Field no.: DFM 24-01-02-06. Borrow-source area B-17, Trachycardium zone, San Joaquin Formation. Echinodermata

Echinoidea

Dendraster sp.

Field no.: DFM 25-01-02-01. Borrow-source area B-17, San Joaquin Formation.

Note with specimens: Bivalves from sandy unit above gypsum zone clays. Borrow-source area B-17, gypsum zone, San Joaquin Formation.

Mollusca

Bivalvia

Anadara trilineata (Conrad)

Indeterminate bivalves

\title{
ESG collected by Eric S. Gore.
}

Field no.: ESG 11-12-01-01. Borrow-source area B-17, Tulare Formation.

Mollusca

Gastropoda

Minute indeterminate gastropods [internal molds]

Field no.: ESG 13-12-01-01. Southwest borrow-source area B-17, Acila zone, San Joaquin Formation. Mollusca

$$
\begin{aligned}
& \text { Bivalvia } \\
& \text { Ostrea sequens Arnold }
\end{aligned}
$$

Field no.: ESG 18-12-01-01. Southwest borrow-source area B-17, Acila zone, San Joaquin Formation. Mollusca

Bivalvia

Macoma cf. M. affinis Nomland 


\section{Mya cf. M. arenaria Linnaeus}

Field no.: ESG 19-12-01-01. Borrow-source area B-17, San Joaquin Formation.

Note with specimens: Northeast section (east of evaporation pond) borrow-source area B-17 below road cut, weathering out from Pecten zone, San Joaquin Formation.

Mollusca

$$
\begin{aligned}
& \text { Gastropoda } \\
& \text { Naticidae, inderminate } \\
& \text { Pteropurpura aff. P. festiva (Hinds) }
\end{aligned}
$$

Field no.: ESG 20-12-01-01. Borrow-source area B-17, San Joaquin Formation.

Note with specimens: From 6" layer in Pecten zone, east of evaporate pond, borrow-source area B-17, San Joaquin Formation.

Mollusca

Gastropoda

Caesia coalingensis Arnold

Field no.: ESG 20-12-01-02. East ridge of borrow-source area B-17, Trachycardium zone, San Joaquin Formation.

Arthropoda

Malacostraca

Indeterminate crab cheliped [identified as Callianassa and cf. Loxyrhynchus by collector]

Field no.: ESG 20-12-01-04. Borrow-source area B-17, San Joaquin Formation.

Note with specimens: From sandy silt beds below Trachycardium interval on ridge, east side of borrow-source area B-17, San Joaquin Formation.

Mollusca

Bivalvia

Ostrea sequens Arnold

Field no.: ESG 20-12-01-05. Borrow-source area B-17, San Joaquin Formation.

Echinodermata

Echinoidea

Dendraster cf. D. coalingensis Twitchell

Field no.: ESG 20-12-01-06. From ridge on the east side of borrow-source area B-17, Trachycardium interval, San Joaquin Formation.

Mollusca

$$
\begin{aligned}
& \text { Bivalvia } \\
& \text { Anadara trilineata (Conrad) } \\
& \text { Tellinidae?, indeterminate } \\
& \text { Gastropoda } \\
& \text { Nassarius sp. }
\end{aligned}
$$

Field no.: ESG 20-12-01-07. From ridge on the east side of borrow-source area B-17, Trachycardium interval, San Joaquin Formation.

Mollusca

Bivalvia 


\author{
Anadara sp. \\ Macoma nasuta (Conrad) \\ Tellina? aff. T. oldroydi Wiedey \\ Trachycardium sp.
}

Field no.: ESG 21-12-01-01. From ridge on the east side of borrow-source area B-17, Trachycardium interval, San Joaquin Formation.

Mollusca

Gastropoda

Calliostoma cf. C. ligatum (Gould)

Calyptraea cf. C. fastigata Gould

Calyptraea inornata (Gabb)

Cancellaria sp.

Nassarius sp.

Glossaulax cf. G. reclusiana (Deshayes)

Pteropurpura aff. P. festiva (Hinds)

Field no.: ESG 21-12-01-02. From ridge on the east side of borrow-source area B-17, Trachycardium interval, San Joaquin Formation.

Arthropoda

$$
\begin{aligned}
& \text { Maxillopoda } \\
& \text { Balanus? sp. }
\end{aligned}
$$

Field no.: ESG 21-12-01-04. Note with specimens: Trachycardium zone.

Mollusca

Bivalvia

Anadara cf. A. trilineata (Conrad)

Gastropoda

Nassarius sp.

Naticidae, indeterminate

Neogastropoda, indeterminatec

Glossaulax cf. G. reclusiana (Deshayes)

Pteropurpura aff. P. festiva (Hinds)

Field no.: ESG 21-12-01-05. Borrow-source area B-17, San Joaquin Formation.

Note with specimens: From 6" layer, Pecten zone located east of pond, borrow-source area B-17, San Joaquin Formation.

Cnidaria

Anthozoa

Mollusca

Indeterminate, very small cup coral

Bivalvia

Indeterminate fragments

Gastropoda

Naticidae, indeterminate

JCB collected by Jason C. Butler

Field no.: JCB 27-11-02-01. Northeast borrow-source area B-17, San Joaquin Formation.

Mollusca 
Bivalvia

Anadara? sp. [small fragment]

Indeterminate micro bivalves or ostracodes

Gastropoda

Cerithiopsidae?, indeterminate

Naticidae, indeterminate

Neogastropoda, indeterminate

Field no.: JCB 27-11-02-02. Northeast borrow-source area B-17, San Joaquin Formation.

Mollusca

Bivalvia

Ostreidae, indeterminate

Field no.: JCB 27-11-02-03. Northeast borrow-source area B-17, San Joaquin Formation.

Mollusca

Bivalvia

Macoma cf. M. affinis Nomland

Mya cf. M. arenaria Linnaeus

Saxidomus cf. S. latus Stewart

Field no.: JCB 27-11-02-04. Northeast borrow-source area B-17, San Joaquin Formation.

Mollusca

Bivalvia

Ostreidae, indeterminate

Field no.: JCB 27-11-02-05. Northeast borrow-source area B-17, San Joaquin Formation. Mollusca Bivalvia

Modiolus cf. M. neglectus Soot-Ryen

Modiolus sp.

Field no.: JCB 27-11-02-06. Northeast borrow-source area B-17, San Joaquin Formation.

Mollusca

Bivalvia

Ostreidae, indeterminate

JSS collected by Jaspal S. Saini

Field no.: JSS 30-12-02-14. Borrow-source area B-17, Tulare Formation.

Mollusca

Bivalvia

Anodonta kettlemensis Arnold

Gonidea coalingensis Arnold

\section{LHF collected by Lanny H. Fisk}

Field no.: LHF 10-03-06-01. Borrow-source area B-17, San Joaquin Formation.

Mollusca

Bivalvia

Macoma cf. M. affinis Nomland 
Field no.: LHF 16-02-07-01. Borrow-source area B-17, Tulare Formation.

Note with specimens: Collected in situ in the Amnicola bed at southwest side of borrow-source area B17, Tulare Formation.

Mollusca

Bivalvia

Ostreidae, indeterminate [internal cast possibly referable to this taxon]

Field no.: LHF 18-02-08-03. Borrow-source area B-17, San Joaquin Formation.

Mollusca

Bivalvia

Indeterminate bivalve

Field no.: LHF 19-02-06-01. Borrow-source area B-17, Trachycardium zone, San Joaquin Formation. Mollusca

Bivalvia

Anadara sp. [fragments]

Saxidomus latus Stewart

Tellina woodringi Adegoke

Gastropoda

Arthropoda

Calyptraea cf. C. fastigiata Gould

Maxillopoda

Balanus? sp.

Field no.: LHF 19-02-06-02. Borrow-source area B-17, Trachycardium zone, San Joaquin Formation. Mollusca

Bivalvia

Tellina woodringi Adegoke

PWR collected by Patrick W. Riseley

Field no.: PWR 01-12-05-01. Borrow-source area B-17, Acila zone, San Joaquin Formation.

Echinodermata

Echinoidea

Dendraster coalingensis Twitchell [abundant]

Field no.: PWR 08-12-05-01. Borrow-source area B-17, San Joaquin Formation.

Mollusca

Gastropoda

Glossaulax cf. G. reclusiana (Deshayes)

Field no.: PWR 09-11-05-01 . Borrow-source area B-17, Trachycardium zone, San Joaquin Formation. Mollusca Bivalvia

Acila castrensis (Hinds)

Anadara cf. A. trilineata (Conrad)

Cryptomya cf. C. californica (Conrad)

Macoma cf. M. affinis Nomland

Modiolus cf. M. neglectus Soot-Ryen

Mytilus sp. 
Solen cf. S. rosaceus Carpenter

Tellina woodringi Adegoke

Tellinidae, indeterminate

Gastropoda

Calyptraea cf. C. inornata (Gabb)

Crepidula princeps (Conrad)?

Crepidula sp.

Naticidae, indeterminate

Arthropoda

Glossaulax reclusiana (Deshayes)

Malacostraca

Indeterminate crab cheliped

Field no.: PWR 15-11-04-01. Borrow-source area B-17, San Joaquin Formation.

Note with specimens: 88' upsection from top of Acila sand, San Joaquin Formation. Borrow-source area B-17, black shale bed at top of Acila zone, San Joaquin Formation.

Mollusca

Bivalvia

Anadara cf. A. trilineata (Conrad) [rare]

Modiolus cf. M. neglectus Soot-Ryen [articulated and common]

Note: Dark, fine grained rocks with pyrite.

Field no.: PWR 16-08-06-01. Borrow-source area B-17, San Joaquin Formation.

Note with specimens: Sandstone in transgressive layer at base of Trachycardium interval. Borrowsource area B-17, base of Trachycardium zone, San Joaquin Formation.

Mollusca

Bivalvia

Anadara cf. A. trilineata (Conrad)

Ostrea cf. O. sequens Arnold

Gastropoda

Caesia coalingensis (Arnold)

Naticidae, indeterminate [common]

Ocenebrina cf. O. lurida (Middendorff)

Arthropoda

Pteropurpura aff. P. festiva (Hinds)

Maxillopoda

Echinodermata

Balanus? sp.

Echinoidea

Dendraster sp.

Field no.: PWR 16-09-05-01. Borrow-source area B-17, base of Trachycardium zone, San Joaquin Formation.

Mollusca

Bivalvia

Anadara trilineata (Conrad)

Cryptomya californica (Conrad)

Macoma cf. M. nasuta (Conrad)

Macoma cf. M. affinis Nomland 


\author{
Macoma sp. \\ Mya cf. M. arenaria Linnaeus \\ Mytilus sp. \\ Ostrea cf. O. sequens Arnold \\ Ostreidae, indeterminate \\ Saxidomus latus Stewart \\ Solen cf. S. rosaceus Carpenter \\ Tellina woodringi Adegoke \\ Calyptraea cf. C. fastigiata Gould \\ Calyptraea cf. C. inornata (Gabb) \\ Littorina? sp. \\ Nassarius? sp. \\ Naticidae, indeterminate \\ Turridae?, indeterminate
}

Gastropoda

Arthropoda

\title{
Maxillopoda \\ Balanus? sp.
}

Field no.: PWR 18-06-06-02. Borrow-source area B-17, marl near base of the Trachycardium zone, San Joaquin Formation.

Mollusca

Bivalvia

Anadara? sp.

Solen? sp.

Tagelus? sp.

Tellina woodringi Adegoke

Tellinidae?, indeterminate

Gastropoda

Arthropoda

Neogastropoda, possibly Pteropurpurea sp.

Malacostraca

Indeterminate crab cheliped

Field no.: PWR 21-10-05-01. Borrow-source area B-17, San Joaquin Formation.

Note with specimens: Pecten interval @ 50'-60' below Trachycardium marker bed. Borrow-source area B-17, Pecten interval, San Joaquin Formation.

Mollusca
Bivalvia
Anadara trilineata (Conrad)
Macoma cf. M. nasuta (Conrad)
Tellinidae?, indeterminate
Gastropoda
Crepidula sp.
Caesia cf. C. coalingensis (Arnold)
Glossaulax cf. G. reclusiana (Deshayes)

Field no.: PWR 21-11-05-01. Borrow-source area B-17, Acila zone, San Joaquin Formation. 
Note with specimens: Interbedded green/brown shale, siltstone, and sandstone between 609.5' and 622.5' above base of Trachycardium zone, borrow-source area B-17, Acila zone, San Joaquin Formation.

Mollusca

Bivalvia

Acila castrensis (Hinds)

Anadara trilineata (Conrad)

Macoma? sp.

Modiolus cf. M. neglectus Soot-Ryen.

Solen? sp.

Tellinidae, indeterminate [large; possibly Tellina woodringi Adegoke]

Gastropoda

Calyptraea. fastigiata Gould

Calyptraea filosa (Gabb)

Catilon iniqua (Stewart)

Crepidula princeps (Conrad)

Crepidula sp. [small casts]

Naticidae, indeterminate

Arthropoda

Glossaulax reclusiana (Deshayes)?

\author{
Maxillopoda \\ Balanus? sp. \\ Malaccostraca \\ Indeterminate crab cheliped
}

Field no.: PWR 21-11-05-02. Borrow-source area B-17, San Joaquin Formation.

Note with specimens: Pyritized fossil from 60' downsection from the top of the Acila zone oyster bed and upper Pecten bed. Borrow-source area B-17, Acila zone, San Joaquin Formation.

Mollusca

Bivalvia

Modiolus sp.

Indeterminate bivalve

Field no.: PWR 22-07-05-01. Borrow-source area B-17, Trachycardium zone, San Joaquin Formation.

Mollusca

Bivalvia

Anadara cf. A. trilineata (Conrad)

Gastropoda

Calyptraea cf. C. inornata (Gabb)

Field no.: PWR 23-08-06-01/PWR 21-11-05-01. Borrow-source area B-17, San Joaquin Formation. Mollusca

Bivalvia

Acila castrensis (Hinds)

Anadara trilineata (Conrad)

Gastropoda

Astyris gauspata (Gould) [Mitrella gouldii of Woodring and others, 1940[1941])

Calyptraea cf. C. fastigiata (Gould)

Calyptraea cf. C. inornata (Gabb) 
Field no.: PWR 27-10-05-01. Borrow-source area B-17, Nevertia zone, San Joaquin Formation.

Mollusca

Gastropodas

Pteropurpura festiva (Hinds)

\section{REH collected by Russ E. Hastings}

Field no.: REH 08-12-03-02. Northeast corner of borrow-source area B-17, San Joaquin Formation.

Mollusca

Bivalvia

Anodonta cf. A. kettlemanensis Arnold

Field no.: REH 12-12-01-02. Borrow-source area B-17, San Joaquin Formation.

Note with specimens: Echinoids below Neverita zone. Borrow-source area B-17, Neverita zone, San Joaquin Formation.

Echinodermata

Echinoidea

Dendraster cf. D. coalingensis Twitchell

Field no.: REH 18-12-01-01. Borrow-source area B-17, San Joaquin Formation.

Note with specimens: "Pecten zone," but is it possible it came from the Neverita (=Polinices) zone?

Matrix looks like Woodring and others, 1940[1941], plate 19. Borrow-source area, coquina layer, San Joaquin Formation.

Mollusca

Bivalvia

Anadara trilineata (Conrad)

Macoma cf. M. nasuta (Conrad) [steinkern]

Macoma? sp.

Modiolus sp.

Ostrea cf. O. sequens Arnold

Ostrea sp.

Solen sp.

Tellina woodringi Adegoke

Veneridae?, indeterminate [abundant fragments]

Indeterminate bivalves

Gastropoda

Caesia coalingensis (Arnold)

Callianax cf. C. pycna Berry

Crepidula princeps (Conrad)

Nassarius sp.

Naticidae, indeterminate [abundant]

Arthropoda

Pteropurpura aff. $P$. festiva (Hinds)

Malacostraca

Callianassa $\mathrm{sp}$.

Indeterminate crab cheliped

Echinodermata

Echinoidea

Dendraster coalingensis Twitchell 
Field no.: REH 20-12-01-01. East of evaporative pond in borrow-source area B-17, Trachycardium zone, San Joaquin Formation.

Mollusca

$$
\begin{aligned}
& \text { Bivalvia } \\
& \text { Anadara } \mathrm{sp} . \\
& \text { Argopecten? sp. } \\
& \text { Ostrea } \mathrm{cf} \text {. O. sequens Arnold } \\
& \text { Gastropoda } \\
& \text { Glossaulax reclusiana (Deshayes) } \\
& \text { Pteropurpura? sp. }
\end{aligned}
$$

Field no.: REH 20-12-01-02. East of evaporative pond in borrow-source area B-17, Trachycardium zone, San Joaquin Formation.

Mollusca

Bivalvia

Anadara trilineata (Conrad)

Field no.: REH 26-12-01-01. Borrow-source area B-17, San Joaquin Formation.

Echinodermata

Echinoidea

Dendraster sp.

\section{Appendix 2: Notes on Taxa Encountered}

\section{Mollusca}

\section{Bivalvia}

Family Nuculidae

Acila castrensis (Hinds) lives today from Punta San Pablo, Baja California, Mexico, to Cook Inlet, Alaska (Bernard, 1983; Coan and others, 2000), in water depths from 5 to $200 \mathrm{~m}$ (Bernard, 1983), 7 to $1,280 \mathrm{~m}$ (Moore, 1983, citing Woodring and others, 1940 [1941]), or 5 to $400 \mathrm{~m}$ (Coan and others, 2000). In the fossil record it has been reported in rocks as old as Miocene (Bernard, 1983; Moore, 1983). California fossil occurrences are in the Capistrano (Vedder,1972), Carreaga (Woodring and Bramlette, 1950), Etchegoin (Arnold, 1909; Arnold and Anderson, 1909 [1910]; Nomland, 1916), Fernando (English, 1914; Durham and Yerkes, 1964) formations, Lomita Marl (Woodring and others, 1946), Merced (Yancey, 1978), Niguel (Kern and Wicander, 1974; as Capistrano Formation; fide Groves, 1991), Ohlson Ranch (Peck, 1960) formations, Palos Verdes Sand (Valentine, 1961), Pico (Kew, 1924; Grant and Gale, 1931), Purisima (Powell, 1998 and citations therein), Rio Dell (Faustman, 1964; Roth, 1979), San Diego, and San Joaquin (Hertlein and Grant, 1972) formations, San Pedro Sand (Oldroyd, 1924, listed as formation; Woodring and others, 1946), Santa Barbara (Oldroyd, 1924), Saugus (= Pico) (Groves, 1991) formations, Timms Point Silt (Clark, 1931; Woodring and others, 1946), Towsley (Kern, 1973) formation, Wildcat Group (Martin, 1916; Roth, 1979), and unnamed terrace deposits in San Diego (Oldroyd, 1924).

Family Arcidae

Anadara trilineata (Conrad) (synonym A. trilineata canalis Conrad) was described by Conrad (1857) as having been collected by Newberry at Santa Barbara, southern California (Woodring and 
others, 1940 [1941]). However, Woodring and others (1940 [1941]) indicate that according to Newberry's itinerary, he was nowhere near Santa Barbara and, therefore, most authors since Woodring and others have not reported it as occurring at or near Santa Barbara.

The Santa Barbara Formation from which it was assumed to have been collected is now considered middle Pleistocene in age (Minor and others, 2002). Addicott (1965), discussing the nassariid gastropod Caesia grammatus (Dall, 1917) reported this Pliocene index fossil as occurring north of Santa Barbara in Goleta; and Powell and others (2009) report possible Pliocene fossils south of Santa Barbara near Rincon Point on the Santa Barbara/Ventura County line. In addition, an unrecorded Los Angeles County Natural History Museum collection contains A. trilineata and was collected in Santa Barbara proper ${ }^{3}$. We accept that $A$. trilineata does not occur younger than Pliocene, even though it has been reported by Roth (1979) from the Scotia Bluffs Sandstone which is, in part, Pleistocene in age. Since, the occurrence of $A$. trilineata has been confirmed in modern collections north, south, and from Santa Barbara proper, we conclude that its type locality could be located at or near Santa Barbara. Elsewhere it has been reported from Kamchatka and Sakhalin Island, Russia, in the western Pacific and from British Columbia, Canada, to southern California in the eastern Pacific in Miocene to Pliocene rocks (Moore, 1983).

\section{Family Mytilidae}

Modiolus neglectus Soot-Ryen occurs from off the mouth of the Salinas River, Monterey County, central California (Soot-Ryen, 1955), south to the Outer Gorda Bank, Baja Calfiornia Sur, Mexico, in water depths from 15 to $110 \mathrm{~m}$ (Coan and others, 2000). Specimens examined here are all crushed to some extent, but still more closely resemble $M$. neglectus than other eastern Pacific species. Modiolus neglectus has not been reported previously as a fossil, and similar specimens were referred to Volsella cf. V. recta (Conrad) by Woodring and others (1940 [1941]) and to M. rectus (Conrad) by Adegoke (1969). Further study and better specimens are needed to confirm the identification of the San Joaquin Formation specimens.

Mytilus californianus Conrad occurs from Cook Inlet, Alaska, south to Punta Rompiente, Baja California Sur, Mexico, in water depths from the intertidal zone to $50 \mathrm{~m}$ (Coan and others, 2000). This species has a limited fossil record, being reported from the Merced (Arnold, 1906) and Rio Dell (Faustman, 1964) formations, the Wildcat Group (Ogle, 1953), unnamed strata on San Nicolas Island (Vedder and Norris, 1963), and at Bahía de San Quintin, Baja California, Mexico (Jordan, 1926). These and additional Pleistocene occurrences indicate a Pliocene, possibly late Pliocene to Holocene age range.

\section{Family Ostreidae}

Ostrea sequens Arnold, although considered synonymous with Dendrostrea? vespertina (Conrad) by most authors (see Moore, 1987), is distinguished here. Squires and others (2006) restrict D.? vespertina to specimens from the ancestral Golfo de California and refer similar larger oysters from the late Miocene and Pliocene of coastal central and southern California to Myrakeena veatchii (Gabb). Woodring and others (1940 [1941]) use the name Ostrea vespertina for some forms from the Kettleman Hills, but following Squires and others (2006) these are now referred to M. veatchii. However, central California Tertiary oysters are smaller than typical $M$. veatchii and have less defined plications. Smaller,

\footnotetext{
${ }^{3}$ Natural History Museum of Los Angeles County, Invertebrate Paleontology collections, field no.: PR57-1. Bottom of hill on east side of Victoria Street in 15-foot cut, Santa Barbara, Santa Barbara County, California. Collected by Peter Rhodda, 1957. Field No.: PR57-1. Unsorted sample. Sample contains the following: Mollusca, Bivalvia, Anadara trilineata (Conrad), Cyclocardia cf. C. californica (Dall) of Woodring and Bramlette, 1950, Dendostrea? aff. D? vespertina (Conrad), Humilaria sp., Lucinoma annulatum (Reeve), Ostrea sp., Panopea abrupta (Conrad), Patinopecten caurinus (Gould), Pecten bellus Conrad, Gastropoda, Astraea gibberosa (Dillwyn) [operculum], Astyris cf. A. gausapata (Gould), Crepidula princeps Conrad, Lirobittium sp., Nassarius sp., Naticidae, indeterminate, and Callianax biplicata (Sowerby).
} 
smooth to moderately plicate oysters from central California are here referred to O. sequens. Larger, strongly plicate specimens from central California are referred to M. veatchii. Ostrea atwoodii Gabb of similar age from central California usually is larger and easily distinguished by its smooth, flat right valve and finely ribbed left valve. The later feature is not seen in any of the specimens examined from the San Joaquin Formation.

\section{Family Unioninae}

Gonidea coalingensis Arnold. The genus Gonidea typified by the modern G. angulata, occurs from southern British Columbia, Canada in the Columbia River system south in Washington, Oregon, Idaho, Nevada, and south-central California. The species lives in lakes, streams, and rivers, preferably in sites that have a constant flow of rather shallow water (typically $<3 \mathrm{~m}$ ) and well-oxygenated substrates, especially when occurring in finer sediments. Gonidea coalingensis has been reported most commonly from the Tulare Formation, although like A. kettlemanensis, the genus also has been recognized in the Etchegoin and San Joaquin Formations (Woodring and others, 1940 [1941]).

\section{Family Anodontinae}

Anodonta kettlemensis Arnold is restricted to the Pliocene to Pleistocene Tulare Formation. The genus Anodonta generally is found in slow moving fresh water and has been recognized from the Etchegoin, San Joaquin, and Tulare Formations in the Kettleman Hills (Woodring and others, 1940 [1941]).

\section{Family Cardiidae}

Trachycardium quadrigenarium (Conrad) is found living from middle California to Baja California Sur, Mexico, in water depths from the intertidal zone to $135 \mathrm{~m}$, in sandy mud with the edges of the valves projecting above the surface (Coan and others, 2000) and in sloughs and sheltered waters of the open coast (Hertlein and Grant, 1972, p. 259). As a fossil, it has been found from the Careaga (Woodring and Bramlette, 1950) and Castaic (Stanton, 1966) formations, Etchegoin (Clark, 1915; Nomland, 1917a), Fernando (Eldridge and Arnold, 1907; Carson, 1925; Soper and Grant, 1932; Durham and Yerkes, 1964; Kennedy, 1975; also as Repetto Formation by Woodring, 1938; Oakeshott, 1958), Jacalitos (Clark, 1929), Merced (Martin, 1916), Millerton (Johnson, 1962), Monterey (Woodring and others, 1946) formations, Neroly Sandstone (Hall, 1960), Niguel (J.G. Vedder, written commun., 1978 in Moore, 2002), Pancho Rico (Durham and Addicott, 1965; Durham, 1974), Pico (Pressler, 1929; Waterfall, 1929; Hoots, 1930; Winterer and Durham, 1962; Meade, 1967), San Diego (Hertlein and Grant, 1972; Rowland, 1972), San Joaquin (Woodring and others, 1940 [1941]), San Pablo (Clark, 1915), San Pedro (Oldroyd, 1925), Saugus (Eaton, 1928; Pressler, 1929; Waterfall, 1929; Hetherington, 1957; Meade, 1967; Groves, 1991 [= Pico Formation]), Santa Barbara (Dibblee, 1966) formations, Cierbo Sandstone (Weaver, 1949), Santa Margarita Sandstone (Grant and Gale, 1931; Nomland, 1917b; Addicott and Vedder, 1963; Durham, 1974; Powell, 2007 and references therein), Temblor (Arnold, 1907b; Grant and Gale, 1931; Schoellhamer and others, 1981), Towsley (Winterer and Durham, 1962; Kern, 1973), and Vaqueros (Arnold and Anderson, 1907; Loel and Corey, 1932) formations, and unnamed Pleistocene strata in California (Kanakoff and Emerson, 1959; Oldroyd and Grant, 1931; Valentine, 1956, 1960) and Baja California, Mexico (Emerson, 1980; Jordan, 1926). These formations indicate a possible maximum age of Oligocene for this species.

\section{Family Veneridae}

Saxidomus latus Stewart differs from the Miocene to Holocene S. nuttalli Conrad, according to Stewart (in Woodring and others, 1940 [1941]), by having “...a wider and longer anterior end...." In addition, specimens from the San Joaquin Formation examined here have a broader posterior end and much subdued sculpture, becoming completely obsolete from about half way up the shell to the umbo and on the anterior end, and being most prominent on the posterior end. Saxidomus latus also has been 
reported from the San Diego Formation (Hertlein and Grant, 1972). These occurrences indicate a Pliocene age for this species.

\section{Family Tellinidae}

Macoma inquinata (Deshayes) [synonyms $M$. inquinata arnheimi Dall; $M$. irus (Hanley) of authors] occurs in the eastern Pacific from the southeastern Bering Sea south to San Pedro, southern California (Foster, 1991), in intertidal areas in bays and offshore to $48 \mathrm{~m}$, below the surf line in silt (Coan, 1971). As a fossil, it has been reported from the following stratigraphic units in California: Battery (Kennedy, 1978), Etchegoin (Arnold and Anderson, 1907, 1909 [1910]; Martin, 1916; Nomland, 1916; Adegoke, 1969), Merced (Martin, 1916; Glen, 1959), Millerton (Kennedy, 1978), Moonstone Beach and Carlotta? (Roth, 1979), Ohlson Ranch (Peck, 1960), Purisima (Powell, 1998 and references therein), Rio Dell (Faustman, 1964), San Diego (Hertlein and Grant, 1972), San Pedro Sand (Arnold, 1903; 1906; Oldroyd, 1924, 1925), San Joaquin (Adegoke, 1969) formations, Santa Margarita Sandstone (Addicott and others, 1978), Timms Point Silt (Clark, 1931), and unnamed Pleistocene deposits in California (Arnold, 1903; Willett, 1937; DeLong, 1941; Addicott, 1966; Wright, 1972; Kohl, 1974; Kennedy, 1978). These fossil and modern occurrences indicate a possible late Miocene through Holocene range.

Macoma affinis Nomland has been reported from the uppermost Etchegoin (Nomland, 1917a), Pancho Rico (Durham and Addicott, 1965), and San Joaquin (Adegoke, 1969) formations in central California. These formations indicate a late Miocene to late Pliocene range for this species.

Macoma nasuta (Conrad) [synonyms Macoma nasuta kelseyi (Conrad)] ranges in age from Oligocene to Holocene (Grant and Gale, 1931). Modern occurrences in the eastern Pacific are along the coast from southern Baja California Sur, Mexico, north to Kodiak Island (Bernard, 1983; McLean, 1978) and Sitkalidak Island, Alaska (Foster, 1991), in water depths from the intertidal zone to $50 \mathrm{~m}$ (Bernard, 1983).

Tellina woodringi Adegoke (synonyms Tellina? cf. T.? oldroydi Wiedey fide Woodring and others, 1940 [1941]). Woodring and others, 1940 [1941] and Adegoke (1969) questioned if it is a true Tellina, but specimens examined here have lateral teeth, confirming their placement in that genus. This species has been reported only from the Etchegoin and San Joaquin formations in the Coalinga District (Adegoke, 1969), central California.

\section{Family Solenidae}

Solen rosaceus Carpenter has been reported from the Fernando (Eldridge and Arnold, 1907), Merced (Fahy, 1974), San Diego (Hertlein and Grant, 1972), and San Pedro (Arnold, 1903) formations, the Wildcat Group (Faustman, 1964), and unnamed strata in southern California (Kanakoff and Emerson, 1959), and Baja California (Jordan, 1926). These occurrences indicate a Pliocene to Holocene age range for this species. Modern occurrences are from Queen Charlotte Islands, British Columbia, Canada, to Bahía San Quintín, Baja California, Mexico, in the middle and lower intertidal zone, in sand and mud of sheltered bays, frequently in Zostera beds (Coan and others, 2000), although Hertlein and Grant (1972) reported it in water depths from the intertidal zone to $46 \mathrm{~m}$, and Bernard (1983) noted its occurrence from the intertidal zone to $45 \mathrm{~m}$. Previous specimens from the Etchegoin and San Joaquin Formations were attributed to S. sicarius Gould (Woodring and others, 1940 [1941]).

\section{Family Myidae}

Cryptomya californica (Conrad) (synonyms C. ovalis Conrad and C. quadrata Carpenter) is common in sand and sandy mud from the intertidal zone to $80 \mathrm{~m}$ (Foster, 1991) along the open coast from Prince William Sound, Gulf of Alaska (Foster, 1991) to northern Peru (McLean, 1978). Grant and Gale (1931) reported this species as a fossil from the Miocene to Pleistocene from western North America, citing references to its occurrence from Washington state south to Baja California Sur, Mexico. 
Mya arenaria Linnaeus has a complicated geologic history (MacNeil, 1965). In California it has been reported as a fossil from the Cierbo Sandstone, Etchegoin, Merced, and San Joaquin formations (MacNeil, 1965). These formations indicate a late Miocene to possibly Pleistocene age (MacNeil, 1965). It then became extinct in the eastern Pacific Ocean sometime during the Pleistocene, but persisted in Japan and the north Atlantic. It was reintroduced into California in 1874 with Atlantic oysters and has successfully established itself from Icy Cape, Arctic Ocean, Alaska, south to Elkhorn Slough, Monterey County, California, with several juvenile records off San Diego, California; it also still occurs in the western Pacific and northern Atlantic (Coan and others, 2000).

\section{Gastropoda}

\section{Family Trochidae}

Calliostoma coalingensis Arnold previously has been reported from the Siphonalia Zone of the Etchegoin Formation and the Acila, Pecten, and Trachycardium zones of the San Joaquin Formation (Woodring and others, 1940 [1941]), as well as the Niguel (Kern and Wicander, 1974 fide Groves, 1991; as ?), Pancho Rico (Durham and Addicott, 1965), and Pico (Soper and Grant, 1932) formations. In addition, C. coalingensis privum Stewart in Woodring and others (1940 [1941]) was described from the Patinopecten zone of the Etchegoin Formation, and C. coalingensis catoteron Woodring and Bramlette was described from the Cebada Member of the Careaga Formation (Woodring and Bramlette, 1950) and also questionably (cf.) occurs in the San Diego Formation (LACM collections). These occurrences indicate a possible late Miocene to late Pliocene age range for $C$. coalingensis and its subspecies.

Calliostoma ligatum (Gould). Modern occurrences are from $60^{\circ} \mathrm{N}$ south to $37^{\circ} \mathrm{N}$ in water depths from the low intertidal zone to $64 \mathrm{~m}$ (CAS wet collection, 7/2007), commonly associated with Macrocystis (kelp) stands. It previously has been reported provisionally (cf.) from the Pliocene (Powell and Stevens, 2000) but occurs in the Pleistocene (Valentine, 1958; Valentine and Lipps, 1963; Powell, 2001) and Holocene (Erlandson and others, 2007) of central and southern California. The occurrence here supports it presence in the Pliocene of California, but the imprecise identification does not confirm it occurrence in the Pliocene.

\section{Family Crepidulidae}

Calyptraea fastigiata (Gould) is identified here as being wider than high, without radial sculpture and with a very slightly concave shell margin. Calyptraea fastigiata occurs from Alaska to southern California and has been dredged commonly from water depths of 18 to $140 \mathrm{~m}$ (10 to 75 fathoms) (Abbott, 1974), although Rice (1971) cites its occurrence from Alaska to Puget Sound, Washington, from the intertidal zone to about $100 \mathrm{~m}(300 \mathrm{ft})$. California Tertiary Calyptraea literature is fraught with confusion and misidentifications and, consequently, the stratigraphic range of this taxon is not known precisely. It has been reported as a fossil from the Anchor Silt (Rodda, 1957), Battery (Kennedy, 1978), Careaga (Woodring and Bramlette, 1950), Fernando (Zinsmeister, 1970), Lomita Marl and Palos Verdes Sand (Woodring and others, 1946), Pico (Winterer and Durham, 1962), Purisima (Cummings and others, 1962; and Perry, 1993) formations, San Pedro Sand (Woodring and others, 1946), Saugus (= Pico) (Groves, 1991), Sisquoc (Woodring and Bramlette, 1950) formations, Timms Point Silt (Woodring and others, 1946; Valentine, 1961), Towsley Formation (Winterer and Durham 1962), and unnamed Pleistocene deposits from Oregon to central California (Addicott, 1966; Wright, 1972; Kennedy, 1978). In addition, Arnold and Hannibal (1913) reported C. fastigiata Gould from the Elk River beds but their concept of this formation included the upper Pleistocene terrace material at Cape Blanco where this taxon occurs (Kennedy, 1978). These formations and its modern occurrences indicate an age range from Pliocene, possibly early Pliocene to Holocene.

Calyptraea filosa (Gabb) is characterized here by its fine, numerous radial ribs. It has been reported from the Capistrano (Kern and Wicander, 1974; =Niguel fide Groves, 1991), Castaic (Stanton, 
1966), Etchegoin (Arnold, 1909; Arnold and Anderson, 1909 [1910]; Martin, 1916; Nomland, 1917a), Fernando (Arnold, 1903; Eldridge and Arnold, 1907; English, 1914; Soper and Grant, 1932; Yerkes, 1972), Jacalitos (Nomland, 1916), Merced (Martin, 1916; Nomland, 1917b; Yancey, 1978), Modelo (Oakeshott, 1958), Monterey (Weaver, 1909), Ohlson Ranch (Peck, 1960), Olcese Sand (Addicott, 1970), Pancho Rico (Durham and Addicott, 1965; Durham, 1974), Pico (Winterer and Durham, 1962; Meade, 1967), Purisima (Martin, 1916; Nomland, 1917a; Allen, 1946), Repetto (=lower Fernando Formation fide Groves, 1991), Round Mountain Silt (Keen, 1943; Addicott, 1970), San Diego (Hertlein, unpublished manuscript), San Joaquin (Woodring and others, 1940 [1941]; Stanton and Dodd, 1976), San Pablo Group (Arnold, 1906; Weaver, 1909; Clark, 1915), Santa Margarita Sandstone (Arnold, 1906; Clark, 1915; Durham, 1974), Saugus (=Pico)(Groves, 1991), Topanga Canyon (Kew, 1924; Schoellhamer and others, 1981), Towsley (Winterer and Durham, 1962; Kern, 1973), and Vaqueros (Arnold, 1909; Arnold and Anderson, 1909 [1910]; Loel and Corey, 1932) formations. If all these occurrences are assigned correctly to this taxon, then it ranges in age from late Oligocene to early Pleistocene. Further study is needed.

Calyptraea inornata (Gabb), as identified here, is higher than wide, without radial sculpture, and with a slightly convex shell margin. This species has been recorded from the Purisima and Vaqueros formations (Powell, 1998). These formations indicate a possible age range of late Oligocene to late Pliocene. However, California Tertiary Calyptraea are poorly defined and, consequently, the stratigraphic range of this taxon is not known precisely.

Crepidula princeps (Conrad) ranges from Alaska to Baja California, Mexico in rocks from Miocene to Pleistocene (Grant and Gale, 1931). The youngest occurrence appears to be Middle Pleistocene based on its occurrence in the Timms Point Silt (Clark, 1931), which, according to Lajoie and others (1991), is Middle Pleistocene in age. Late Pleistocene occurrences, such as at Newport Bay, Orange County, California (Kanakoff and Emerson, 1959), represent reworked specimens judging by their preservation and color.

\section{Family Naticidae (35)}

Glossaulax reclusiana (Deshayes) (synonym Neverita recluziana alta Dall) is fairly common in lagoons and shallow bays (not characteristic of offshore sandy bottoms) from Crescent City, California $\left(42^{\circ} \mathrm{N}\right)$, to Mazatlan, Sinaloa, Mexico $\left(23^{\circ} \mathrm{N}\right)$, although it is rare north of Mugu Lagoon, Ventura County, California (34N) (Marincovich, 1977; McLean, 1978). Marincovich (1977) reported this species in rocks from the Eocene to Pleistocene from Vancouver Island, British Columbia, Canada to the Golfo de California, Mexico.

\section{Family Muricidae (43)}

Ocenebrina lurida (Middendorff) is common at low tide north of Point Conception, Santa Barbara County, California, and obtained only occasionally at subtidal depths in southern California (McLean, 1978). It ranges from Sitka, Alaska, south to Santo Tomas, Baja California Sur, Mexico (McLean, 1978). James McLean (LACM retired) is in the process of describing several new species of similar Ocenebrina, and the identification of the fossil specimens could change. That said, O. lurida has been reported from the Careaga (Woodring and Bramlette, 1950), Fernando (Arnold, 1907a; Arnold, 1907b; Arnold and Anderson, 1907; Eldridge and Arnold, 1907; Moody, 1916) Millerton (Johnson, 1962; Kennedy, 1978) formations, Palos Verdes Sand (Woodring and others, 1946), San Pedro Sand (Oldroyd, 1925), Saugus Formation (Meade, 1967; Groves, 1991 [= Pico]), and unnamed Pleistocene deposits from throughout California (Arnold, 1908; Grant and Gale, 1931; Hoots, 1930; Delong, 1941; Valentine, 1958; Vedder and Norris, 1963; Kohl, 1974; Marincovich, 1976; Kennedy, 1978). These formations indicate an age range of late Pliocene to Holocene.

Pteropurpura festiva (Hinds). According to McLean (1978) large specimens are common in muddy and rocky areas within bays, whereas smaller specimens occur on the exposed coast at low tide and in sublittoral depths on rocky bottoms from Santa Barbara, California, to Bahia Magdalena, Baja 
California Sur, Mexico. In the fossil record it is found in the Niguel (Kern and Wicander, 1974; formation assignment after Groves, 1991), Pancho Rico (Durham and Addicott, 1965), and San Diego (LACM collections) formations, and in unnamed Pliocene rocks in Newport Bay, Orange County, southern California (Zinsmeister, 1970; J.D. Mount, written commun., 1979). It is also common in the Pleistocene of southern California (see Grant and Gale, 1931; Woodring and others, 1946). Closer examination is needed to see if $P$. festivus from the Pancho Rico and San Joaquin are actually this species or something similar.

Pteropurpura aff. P. festiva (Hinds). This is in part Jaton cf. J. festvus (Hinds) of Woodring and others (1940 [1941]) and is not Pteropurpura festiva. It lacks the backward rolled varices and fine brown spiral lines characteristic of $P$. festiva. This is likely a new species, but further study and better specimens are needed before it can be described.

\section{Family Columbellidae (48)}

Astyris gauspata (Gould) has been found from Bechevin Bay on the northwest side of the Alaska Peninsula, Alaska, south to Punta San Pablo, Baja California Sur, Mexico, on soft bottoms from 30 to $200 \mathrm{~m}$ (McLean and Gosliner, 1996) water depths. Grant and Gale (1931) report the oldest occurrence of A. gauspata as from the late Miocene Montesano Formation in Washington, citing Weaver, but without giving a date or reference. Discounting this occurrence, the next oldest occurrence is the late Miocene Coos Conglomerate Member of the Empire Formation in Oregon (Howe, 1922), and then the Pliocene part of the Wilson Grove Formation in central California (Powell and others, 2004), where it is common. The oldest occurrence of Mitrella gouldii (Carpenter), which McLean (1996) considered synomyous, is in the late Pliocene (Moody, 1916; Grant and Gale, 1931; Woodring and Bramlette, 1950; Powell and others, 2007). Together these occurrences give an age range of Miocene, probably late Miocene, through Holocene. However, because many California Columbellidae have been confused in the past, the geologic range of this species should be reviewed further.

\section{Family Nassariidae (49)}

Caesia coalingensis (Arnold), formerly assigned to the genus Nassarius, has been reported from the Etchegoin (unrestricted) of Arnold (1909; includes the San Joaquin Formation of later workers), Pancho Rico (Addicott, 1965), and San Joaquin (Woodring and others, 1940 [1941]) formations. These units range in age from late Miocene to late Pliocene. Further refinement of the age is not possible without detailed stratigraphic occurrences in dated sections. It is interesting that, in the Kettleman Hills Landfill section, Caesia coalingensis stratigraphically precedes Carlton iniquus, with no overlap between the two.

Catilon iniqua (Stewart), formerly in the genus Nassarius, is reported from the Etchegoin Formation south of Coalinga (Arnold, 1909) and from the Kettleman Hills (Woodring and others, 1940 [1941]), from the Towsley(?) Formation in Los Angeles County (Addicott, 1965), and from undetermined rocks in a core near Tipton, California (Grant and Gale, 1931), and in the Diablo Range, San Benito 15' Quadrangle (UCMP collections cited by Addicott, 1965). Using the Etchegoin and Towsley(?) Formations occurrences, this species has a questionable age range from the late Miocene through the Pliocene.

Nassarius is used here for indeterminate taxa previously assigned to this genus (family Nassariidae). Many of the California species are now referred to the former subgenera Hima or Caesia (of Addicott, 1965) following McLean (2007). Other changes within the family are likely to occur with publication of McLean's future review of northeastern Pacific gastropods.

Family Olivellidae (53)

Callianax pycna Berry has a modern occurrence from Seaside Rock, Clatsop County, Oregon (Gifford and Gifford, 1948), south to Morro Rock, San Luis Obispo County, California, in water depths from the intertidal zone to $27 \mathrm{~m}$ (Burch, 1944-46). In the fossil record, C. pycna has been confused with 
C. biplicata (Sowerby), C. intorta (Carpenter), and C. pedroana (Conrad). Judging from published pictures and specimens examined in collections at CAS, LACM, and UCMP, C. pycna occurs in the Careaga Sandstone (Woodring and Bramlette, 1950), Carlotta(?), Elk River, Moonstone Beach, (Roth, 1979), and Purisima (Arnold, 1908; Martin, 1916; Allen, 1946; Touring, 1959; Cummings and others, 1962; Addicott and others, 1978; Perry, 1993) formations, and from Pleistocene terrace deposits at Año Nuevo State Reserve, central California (Addicott, 1966). These occurrences indicate a likely early Pliocene to Holocene age range for C. pycna.

\section{Echinodermata}

\section{Echinoidea}

\section{Family Dendrasteridae}

Dendraster coalingensis (Arnold) is known only from the Etchegoin and San Joaquin formations in central California (Kew, 1920; Grant and Hertlein, 1938), although it has provisionally (cf.) been reported from the Tinaquaic Sandstone Member of the Sisquoc Formation (Woodring and Bramlette, 1950). These formations indicate a possible late Miocene to late Pliocene age. 